\title{
A New Root-Knot Nematode, Meloidogyne baetica n. sp. (Nematoda: Heteroderidae), Parasitizing Wild Olive in Southern Spain
}

\author{
Pablo Castillo, Nicola Vovlas, Sergei Subbotin, and Alberto Troccoli
}

First author: Instituto de Agricultura Sostenible, Consejo Superior de Investigaciones Científicas (CSIC), Apdo. 4084, 14080 Córdoba, Spain; second and fourth authors: Istituto per la Protezione delle Piante, Sezione di Bari, Nematologia Agraria, Consiglio Nazionale delle Ricerche, (CNR), Via G. Amendola 165/A, 70126 Bari, Italy; and third author: Institute of Parasitology of the Russian Academy of Sciences, Leninskii prospect 33, Moscow 117071, Russia.

Accepted for publication 24 March 2003.

\begin{abstract}
Castillo, P., Vovlas, N., Subbotin, S., and Troccoli, A. 2003. A new rootknot nematode, Meloidogyne baetica $\mathrm{n}$. sp. (Nematoda: Heteroderidae), parasitizing wild olive in southern Spain. Phytopathology 93:1093-1102.

High infection rates of wild olive (Olea europaea sp. sylvestris) feeder roots and soil infestation by a new root-knot nematode were found in sandy soil at Vejer de la Frontera (Cádiz), southern Spain. Morphometric traits and analyses of the nematode esterase electrophoretic pattern as well as of the internal transcribed spacer 1 (ITS1)-5.8S gene and D2-D3 fragment of the $28 \mathrm{~S}$ gene of rDNA showed that specimens differed clearly from known root-knot nematodes. Studies of host-parasite relationships showed a typical susceptible reaction in naturally infected

we suggest the common name, "Mediterranean olive root-knot nematode." The species is herein described and illustrated, and named as Meloidogyne baetica $\mathrm{n}$. sp. The new root-knot nematode can be distinguished from other Meloidogyne spp. by (i) the perineal pattern, which is almost similar to that of $M$. artiellia, characterized by distinct inner striae forming two distinct longitudinal bands, extending throughout the perineum to just below the vulva; (ii) female excretory pore anterior to the level of stylet knobs, excretory pore distance from anterior end/length of stylet ratio extremely small (0.5 to 0.8$)$; and (iii) second-stage juveniles with elongate-conoid tail. Phylogenetic trees derived from maximum parsimony analyses showed that $M$. baetica is closely related to $M$. artiellia, the cereal and legume root-knot nematode.
\end{abstract} wild olive plants and in olive planting stocks (cvs. Arbequina and Picual) artificially inoculated with the nematode. However, the nematode did not reproduce in artificially inoculated chickpea, pea, and tomato. Because of the ability of this new nematode to infect wild and cultivated olives only,

Olive (Olea europaea sp. europaea L.) is grown extensively in the Mediterranean Basin, the subtropical regions of Australia, southern Africa, and North and South America. About 90\% of 8 million hectares of olive grown worldwide in 2001 are located in Mediterranean countries (15); of which, more than $1.3 \times 10^{6}$ ha are found in Andalusia, southern Spain (3). At present, olives constitute a combination of uncultivated forms and cultivated varieties (39). In numerous areas undisturbed by cultivation, the wild olive (O. europaea sp. sylvestris (Miller) Hegi) is a common component of soils and communities known as Oleo-Lenticetum and Rosmarino-Ericion, which are called "matorral" in Spain (30).

In Spain, olive groves are established using self-rooted, improved cultivars, of which cvs. Arbequina and Picual are widely used because of their large yield and oil quality. Conversely, in other Mediterranean countries such as Italy, olive groves are established using selections from wild olive trees as rootstocks.

Olive roots can be infected by a range of plant-parasitic nematodes. Nematode species associated with olive trees include Mesocriconema xenoplax (Raski) Loof \& De Grisse (=Criconemella xenoplax (Raski) Luc \& Raski), Helicotylenchus spp., Heterodera mediterranea Vovlas, Inserra \& Stone, Meloidogyne spp., Pratylenchus spp., Xiphinema spp., and Rotylenchulus spp. (5,10,25, 26). Also, several authors have reported impairment of cultivated olive due to root-knot nematodes $M$. arenaria (Neal) Chitwood,

Corresponding author: P. Castillo; E-mail address: ag1cascp@uco.es

Publication no. P-2003-0623-02R

(c) 2003 The American Phytopathological Society
Additional keywords: esterase pattern, histopathology, host suitability, phylogenetic relationship.
M. incognita (Kofoid and White) Chitwood, and M. javanica (Treub) Chitwood (24,31). However, to our knowledge, this is the first report of root-knot nematodes on wild olive. The accurate identification and pathogenic characterization of root-knot nematodes attacking wild and cultivated olives are needed as an initial step in designing effective control measures. This is especially important in the search for possible sources of host plant resistance against Meloidogyne spp. to reduce the initial nematode population density (32).

Nematode surveys in established (more than 50 years old) natural wild olive communities growing in southern Spain revealed high infection rates of olive feeder roots by a root-knot nematode (P. Castillo, unpublished data). This root-knot nematode morphologically resembles the cereal and legume root-knot nematode, M. artiellia Franklin (16), which prompted us to perform a comparative study. Some reliable diagnostic approaches commonly used to identify and compare certain root-knot nematode species include analyses of isozyme patterns and ribosomal DNA sequences. The analysis of isozyme electrophoretic patterns proved valuable in separating several species and races of Meloidogyne $(13,20)$. Similarly, sequences of internal transcribed spacer (ITS) and intergenic spacer regions of ribosomal DNA were used successfully in the diagnostics and study of phylogenetic relationships within species and populations of root-knot nematodes $(4,7,8,18,29,37,38)$.

This work describes a new nematode species found infecting wild olives and compares this new species with $M$. artiellia using morphological traits and isozyme electrophoretic patterns. Also, the relationship with other root-knot nematodes was studied based 
on maximum parsimony analyses of sequences from the ITS region and the D2-D3 fragment of the rDNA 28S gene. Additionally, the host-parasite relationships were studied in naturally infected wild olive and in commercial olive planting stocks and tomato (Lycopersicon esculentum Mill.) plants artificially inoculated with the nematode.

\section{MATERIALS AND METHODS}

Nematode populations. Samples of wild olive roots, together with rhizosphere and bulk soil, were collected with a shovel from the upper $20 \mathrm{~cm}$ of soil in established wild olive communities at Vejer de la Frontera (Cádiz), southern Spain, during May 2000 and October 2001. For diagnosis and identification, females were collected directly from galled roots, whereas males, eggs, and second-stage juveniles (J2) of nematodes were extracted from the rhizosphere by centrifugal-flotation (6) and from feeder roots of wild olives by blending in a $0.5 \% \mathrm{NaOCl}$ solution for $4 \mathrm{~min}$ (19). Inoculum of $M$. baetica for histopathological and host plant inoculation assays was increased on wild olive planting stocks. A single egg mass was placed beneath the roots of individual 2- to 3 -month-old wild olive planting stocks in 12-cm pots filled with sterile loamy soil. Inoculated plants were incubated in a growth chamber adjusted to $25 \pm 1{ }^{\circ} \mathrm{C}, 60$ to $90 \%$ relative humidity, and a 14-h photoperiod of fluorescent light at $360 \pm 25 \mu \mathrm{E} \mathrm{m}^{-2} \mathrm{~s}^{-1}$. Three months after inoculation, when nematode egg masses were fully formed on roots of wild olive planting stocks, plants were uprooted and their roots were gently washed free of adhering soil, finely chopped, and blended in a $0.5 \% \mathrm{NaOCl}$ solution for 4 min (19). Eggs and J2 were collected on a 500-mesh sieve and gently rinsed with tap water for $5 \mathrm{~min}$ to remove residual bleach. Root debris were then separated and discarded by centrifugal-flotation (6). Inoculum was increased several times using the same procedure. Average nematode populations were determined by counting eggs and $\mathrm{J} 2$ in $101-\mathrm{ml}$ aliquots, and the inoculum dose was adjusted with sterile water.

A population of $M$. artiellia naturally infecting roots of chickpea (Cicer arietinum L.) at Minervino Murge (Bari Province), southern Italy, was arbitrarily selected for comparisons in morphology, isozyme phenotypes, and molecular analyses.

Morphological studies. The source of materials for morphological studies was specimens collected on the rhizosphere and roots of naturally infected wild olives at Vejer de la Frontera (Cádiz), southern Spain. J2 and males were infiltrated in glycerin by standard procedures $(14,34)$. Glycerin-infiltrated specimens were used for studies on morphometric traits and drawings with camera lucida. All measurements are in micrometers unless otherwise stated. Perineal patterns of mature females were prepared. Root tissues were teased apart with forceps and a half spear to remove adult females. The head and neck region of nematodes were excised, and the posterior end was cleared in a solution of $45 \%$ lactic acid to remove remaining body tissues. Then, perineal patterns were trimmed and transferred to a drop of glycerin and processed as described by Hartman and Sasser (17). At least 50 perineal patterns were examined for species identification.

Esterase isozyme analysis. Isozyme phenotypes of mature females were determined at the Departamento de Zoologia, Universidade de Coimbra (Portugal). Single or five-specimen groups (coming from different galls of the same population) of young egg-laying females of $M$. baetica and $M$. artiellia from naturally infected roots of wild olive and chickpea at Vejer de la Frontera (Spain) and Minervino Murge (Italy), respectively, were used for isozyme electrophoretic studies following the procedure of Karssen et al. (23).

Molecular analysis. The source of materials for molecular studies was specimens of $M$. baetica collected on naturally infected wild olive roots at Vejer de la Frontera (Cádiz), southern Spain, and specimens of $M$. artiellia collected on naturally infected chickpea roots at Minervino Murge (Bari Province), southern Italy. DNA extraction and polymerase chain reaction (PCR) assays were performed according to Subbotin et al. (35). The ITS1-5.8S-ITS2 and the D2-D3 of 28S of rDNA were amplified using the following primer sets: 5367 (5'-TTGATTACGTCCCTGCCCTTT-3') and F195 (5'-TCCTCCGCTAAATGATATG-3'); and D2A (5'-ACAAGTACCGTGAGGGAAAGTTG-3') and D3B (5'-TCGGAAGGAACCAGCTACTA-3') as described by Schmitz et al. (33) and De Ley et al. (9), respectively. PCR products were purified with a gel extraction kit (QIAquick; Qiagen GmbH, Germany) and used for direct DNA sequencing. DNA fragments were sequenced in both directions using the same amplification primers with a terminator cycle sequencing ready reaction kit (BigDye; Perkin-Elmer Applied Biosystems, UK) according to the manufacturer's instructions. The resulting products were purified and run on a DNA sequencer (Model 377; PE Applied Biosystems). The ITS and D2-D3 sequences of M. baetica n. sp. and M. artiellia were deposited as GenBank Accession Nos. AY150366 to AY150369. The sequences of the other nematode taxa were obtained from GenBank (7,18,29; Y. Saeki, E. Kawano, C. Yamashita, S. Akao, and Y. Nagatomo, unpublished data; and G. Tenente, I. T. De Ley, G. Karssen, A. Vierstraete, J. Vanfleteren, and P. De Ley, unpublished data). The computer program ClustalX 1.64 with default options was used for alignment of sequences. The ITS sequences of $M$. baetica n. sp. and $M$. artiellia were aligned with seven published DNA sequences of root-knot nematodes. The D2-D3 fragment sequences were aligned with nine known sequences of root-knot nematodes and two sequences of Pratylenchus spp. (12) used as outgroup taxa. The alignments used in this study are available by request from P. Castillo.

Unweighted maximum parsimony analysis of alignments was performed using PAUP 4.0 (36) with heuristic search. Gaps were treated as missing data. Bootstrap analysis with 1,000 replicates was conducted to assess the degree of support for each branch on the tree.

Histopathology. Galled roots from wild olive plants naturally infected by $M$. baetica and from 'Arbequina' and 'Picual' planting stocks artificially inoculated with the increased inoculum were selected for histopathological studies. Roots were gently washed free of adhering soil and debris, and individual galls were selected with healthy roots. The root tissues were fixed in formaldehyde chromo-acetic solution for $48 \mathrm{~h}$, dehydrated in a tertiary butyl alcohol series (40-70-85-90-100\%), and embedded in $58^{\circ} \mathrm{C}$ (melting point) Paraffin for histopathological observations. Embedded tissues were sectioned with a rotary microtome. Sections of 10 to $12 \mu \mathrm{m}$ thick were placed on glass slides, stained with safranin and fast-green, mounted permanently in $40 \%$ xylene solution of a polymethacrylic ester (Synocril 9122X), examined microscopically, and photographed (22). The same procedures were used for histopathological examination of tomato roots artificially inoculated with $M$. baetica.

Host plant bioassay. Roots of wild olive, used to increase nematode inoculum, were finely chopped and shaken in a $0.5 \%$ $\mathrm{NaOCl}$ solution for $4 \mathrm{~min}$ (19). For inoculum, eggs were extracted as previously described. Tomato (cv. Roma), chickpea (cv. UC 27), and pea (Pisum sativum L. 'Verdone Fulminante') plants (2 to 4 weeks old) were each transplanted into 1-liter clay pots filled with sterile clay loam soil. Plants were then inoculated by pipetting approximately 10,000 eggs in $10 \mathrm{ml}$ of sterile water into each pot around the root system of a seedling. There were four inoculated plants per test host. Plants were incubated in a growth chamber adjusted to $25 \pm 1{ }^{\circ} \mathrm{C}, 60$ to $90 \%$ relative humidity, and a 14-h photoperiod of fluorescent light at $360 \pm 25 \mu \mathrm{E} \mathrm{m}^{-2} \mathrm{~s}^{-1}$. Plants in pots were watered as needed and fertilized with $100 \mathrm{ml}$ of a $0.1 \%$ 20-5-32+micronutrients hydro-sol fertilizer (Haifa Chemicals Ltd., Haifa, Israel) solution every 2 weeks. Sixty days after inoculation, plants were removed from pots, the root system was washed free of soil and blended in a $0.5 \% \mathrm{NaOCl}$ solution for 
$4 \mathrm{~min}$, and nematode eggs were extracted as described previously (19). The procedures described previously were used to test the host suitability of wild olive and cultivated 'Arbequina' and 'Picual' olive planting stocks to M. artiellia.

\section{RESULTS AND DISCUSSION}

Description of $M$. baetica $\mathbf{n}$. sp.: Holotype female: $\mathrm{L}=845$; maximum body width $=516 ; \mathrm{a}=1.64 ;$ stylet length $=18$; dorsal
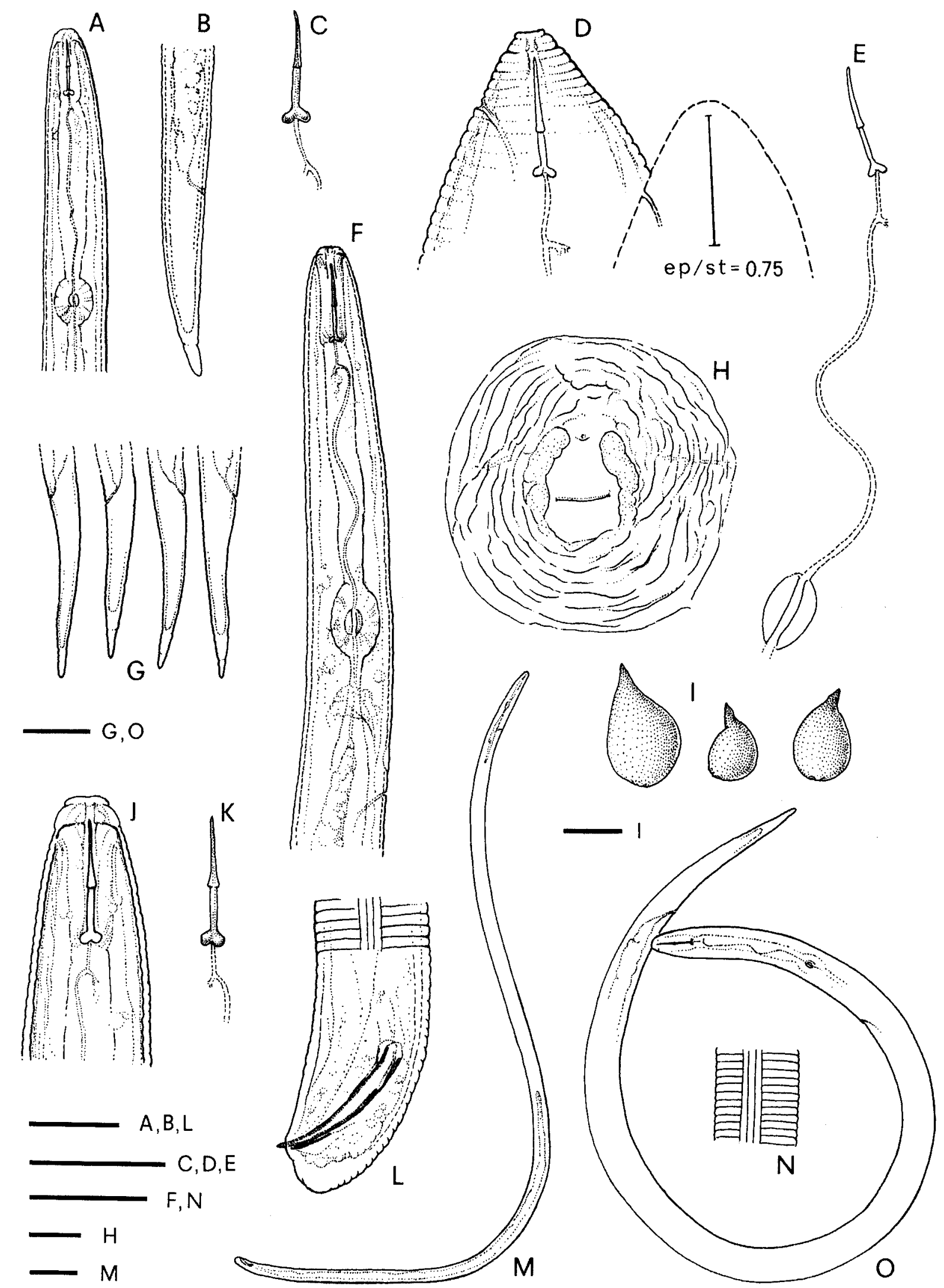

Fig. 1. Line drawings of Meloidogyne baetica n. sp. second-stage juveniles: A and F, anterior body region; $\mathbf{B}$ and $\mathbf{G}$, variation in tail regions; $\mathbf{C}$, stylet; and $\mathbf{O}$, outline of whole specimen. Female: D, lip region; E, stylet; H, perineal pattern; and I, outline of whole specimens. Male: J, lip region; K, stylet; L, tail; and M, outline of whole specimen. N, lateral field of second-stage juvenile at mid-body. (Scale bars: $\mathbf{I}=500 \mu \mathrm{m} ; \mathbf{M}=100 \mu \mathrm{m} ; \mathbf{A}$ to $\mathbf{O}=20 \mu \mathrm{m}$ ). 
esophageal gland opening $(\mathrm{DGO})=4.0$; excretory pore from anterior end $=16$; excretory pore distance from anterior end/ length of stylet $(\mathrm{EP} / \mathrm{ST}$ ratio $)=0.9$; vulva length $=24$; and distance from vulva to anus $=22$.

Female paratypes $(n=20): \mathrm{L}=911 \pm 163$ (775 to 1,263$)$; maximum body width $=523 \pm 88$ (469 to 559$) ; \mathrm{a}=1.6 \pm 0.1$ (1.5 to $1.7)$; stylet length $=17.5 \pm 0.8$ (17 to 19$)$; $\mathrm{EP} / \mathrm{ST}$ ratio $=0.7 \pm$ 0.1 ( 0.5 to 0.8$)$; vulva length $=20 \pm 2.7$ (17 to 24$)$; and distance from vulva to anus $=21 \pm 1.6$ (19 to 25 ). All measurements are in micrometers. Body completely enclosed by galled tissue: body pearly white, pear shaped and anterior body portion commonly off-center from a median plane and with almost terminal vulva. Neck usually short, not bent (Fig. 1). Esophageal gland with one large dorsal lobe with one nucleus; two small nucleated subventral gland lobes, variable in shape, position, and size, usually posterior to dorsal gland lobe. Two large esophago-intestinal cells near junction of metacorpus and intestine. Cephalic framework distinct, lip region offset and bearing one annulus. Excretory pore distinct, constantly anterior to the level of knobs of stylet. Stylet strong and small, slightly curved dorsally. Perineal patterns characteristic (as illustrated in Figure 2), typically formed of striae and ridges of the cuticle, the latter being more pronounced nearer the vulva and
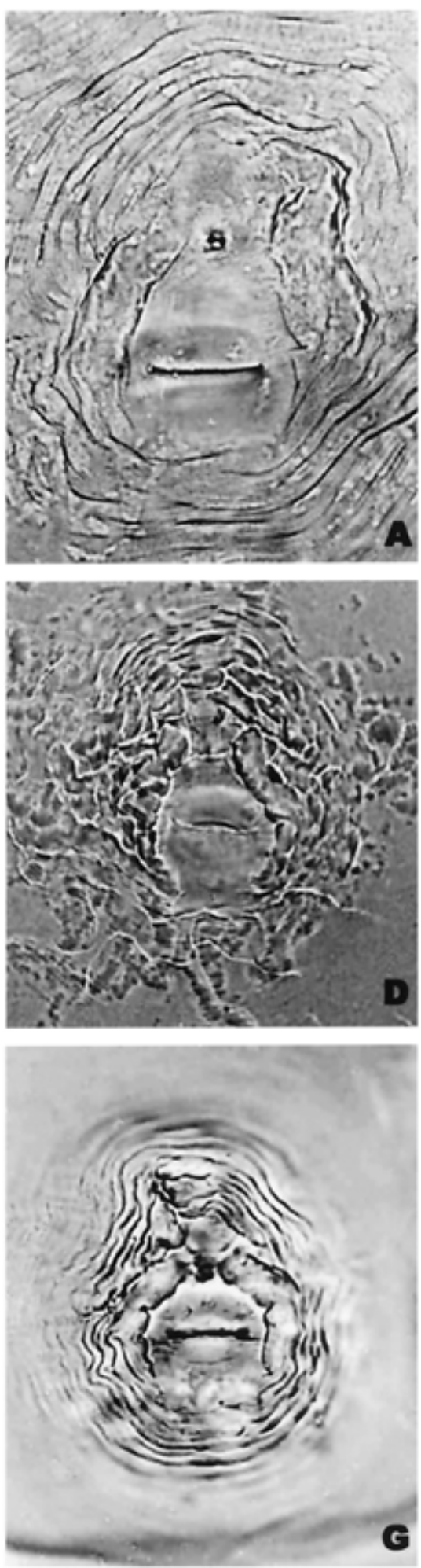
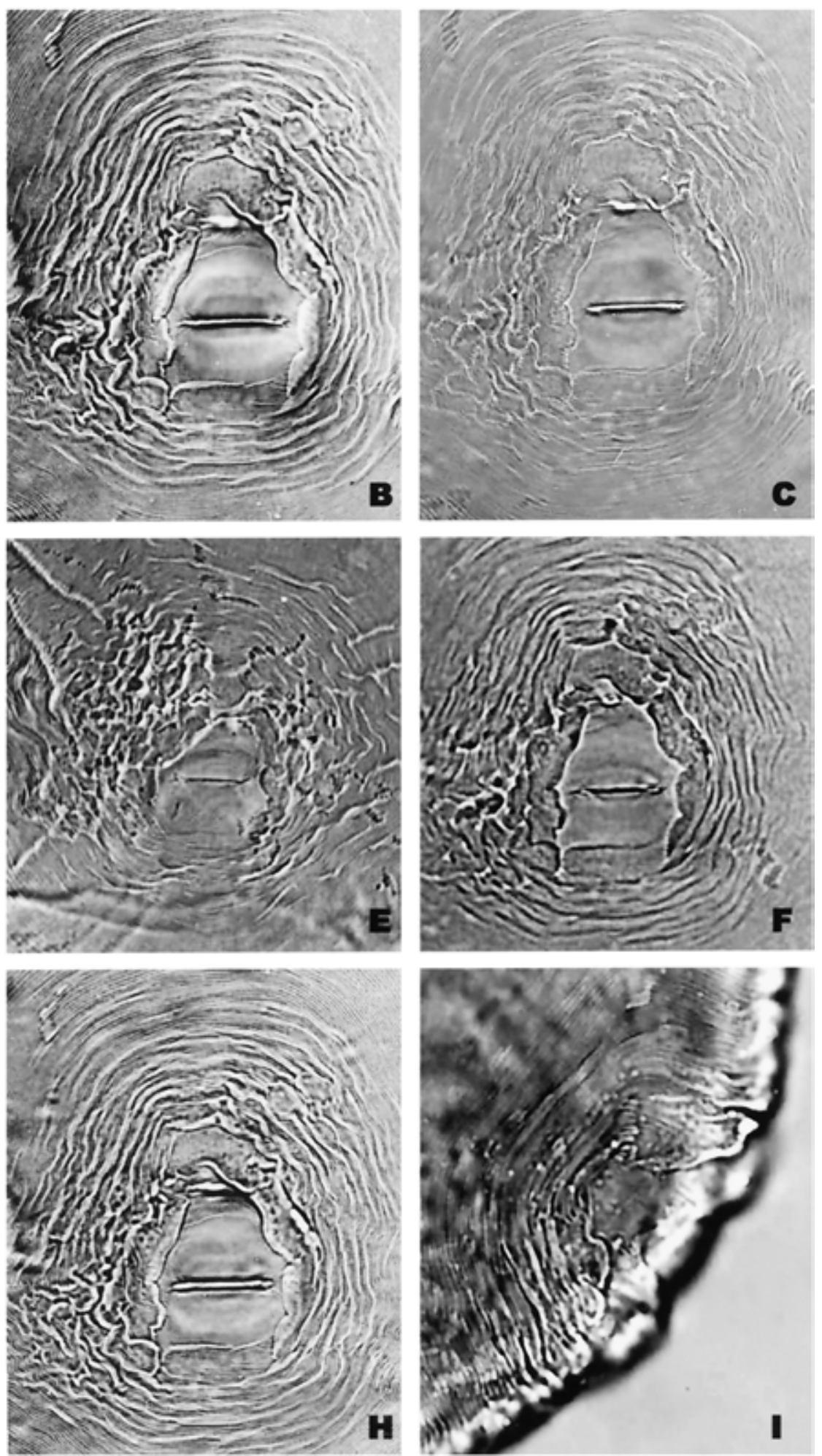

Fig. 2. Photomicrographs of perineal patterns of Meloidogyne baetica $\mathrm{n}$. sp. A to $\mathbf{H}$, typical variation; and $\mathbf{I}$, terminal cone. 
anus. The dorsal arch encloses the usually quite distinct phasmids, and the anus, situated at the center. The vulva slit is centrally located at the unstriated area, nearly as wide as the vulva-anus distance. Commonly, large egg sac occurs outside the small root gall, containing up to 435 eggs ( $n=15$ egg masses counted).

Eggs $(n=14): \mathrm{L}=119 \pm 9.1$ (109 to 139$)$; maximum body width $=42 \pm 2.4$ (38 to 46 ); and L/W (body length/maximum body width $)=2.6 \pm 0.5$ (2.5 to 3.2$)$. Egg shell hyaline and unsculptured when observed under light microscope. J2 in full embryonated eggs folded three to four times (Fig. 3).

Allotype (male): $\mathrm{L}=1,810 ; \mathrm{a}=58 ; \mathrm{b}=13.2 ; \mathrm{c}=129$; stylet length $=18 ; \mathrm{DGO}=4.0$; center of median bulb from anterior end $=$ 103; excretory pore from anterior end $=141$; tail $=14$; spicules $=$ 28; gubernaculum $=9$; lip region $=6.0$ in height and 8.5 in width; body annulation $=2.7$ apart; and lateral field width $=10$.

Male paratypes $(n=22): \mathrm{L}=1,811 \pm 406(1,545$ to 2,205$) ; \mathrm{a}=$ $62 \pm 7.0$ (58 to 75$) ; \mathrm{b}=12.4 \pm 2.2(9.8$ to 15.7$) ; \mathrm{b}^{\prime}=8.2 \pm 1.4$ (6.5 to 10.1$) ; \mathrm{c}=171 \pm 37$ (131 to 242$)$; stylet length $=17 \pm 1.6$ (16 to 19$)$; $\mathrm{DGO}=4.0 \pm 0.5$ (3.5 to 5.5$)$; center of median bulb from anterior end $=109 \pm 17$ (95 to 132 ); $\mathrm{T}=36 \pm 4.8$ (31 to 48); spicules $=27 \pm 4.0$ (24 to 36$)$; gubernaculum $=12 \pm 1.5$ (10 to $14)$; and tail $=11 \pm 1.7$ (9 to 14 ). Body vermiform, tapering anteriorly; tail rounded, with twisting posterior body portion. Lip region slightly offset, $6.0 \pm 0.2$ (5.5 to 6.0 ) high, $9.0 \pm 0.6$ (8.5 to 11) wide, with large labial annulus and a prominent post-labial annulus. Body annulation distinct, $2.5 \pm 0.1$ wide at midbody. Lateral field not areolated, composed of four incisures, forming three bands, $9 \pm 1.0$ ( 8 to 11 ) wide, about one-third of body width. Stylet knobs rounded, $2.5 \pm 0.1$ wide. Excretory pore $157 \pm 18$ (137 to 179) from anterior end. Testis one, occupying 31 to $48 \%$ of the body cavity. Spicules and gubernaculum rather short. Tail bluntly rounded and annulated (Fig. 3).

$J 2(n=26): \mathrm{L}=403 \pm 136$ (394 to 422$) ; \mathrm{a}=29 \pm 1.2$ (28 to 32); $\mathrm{b}=$ not detected; $\mathrm{c}=7.9 \pm 0.4$ (7.3 to 8.4); stylet length $=13.5 \pm$ 0.5 (13 to 14$)$; maximum body width $=13.5 \pm 0.5$ (13 to 14$)$; and excretory pore from anterior end $=93 \pm 5.3$ (85 to 100). Body slender, tapering to an elongated tail. Labial framework weak, vestibule and vestibule extension distinct but not strongly sclerotized, except at anterior terminus. Stylet slender, cone weakly expanding at junction with shaft, knobs rounded, $1.5 \pm 0.2$ (1.5 to $2.0)$ in width. Distance from stylet knobs to dorsal gland orifice, $4.0 \pm 0.7$ (3 to 5). Metacorpus broadly oval, valve large and heavily sclerotized. Esophago-intestinal junction at level of nerve ring. Excretory pore slightly behind nerve ring, opening through hemizonid. Lateral field with four incisures, $3 \mu \mathrm{m}$ wide, not areolated. Phasmids small, distinct, slightly offset ventrally within
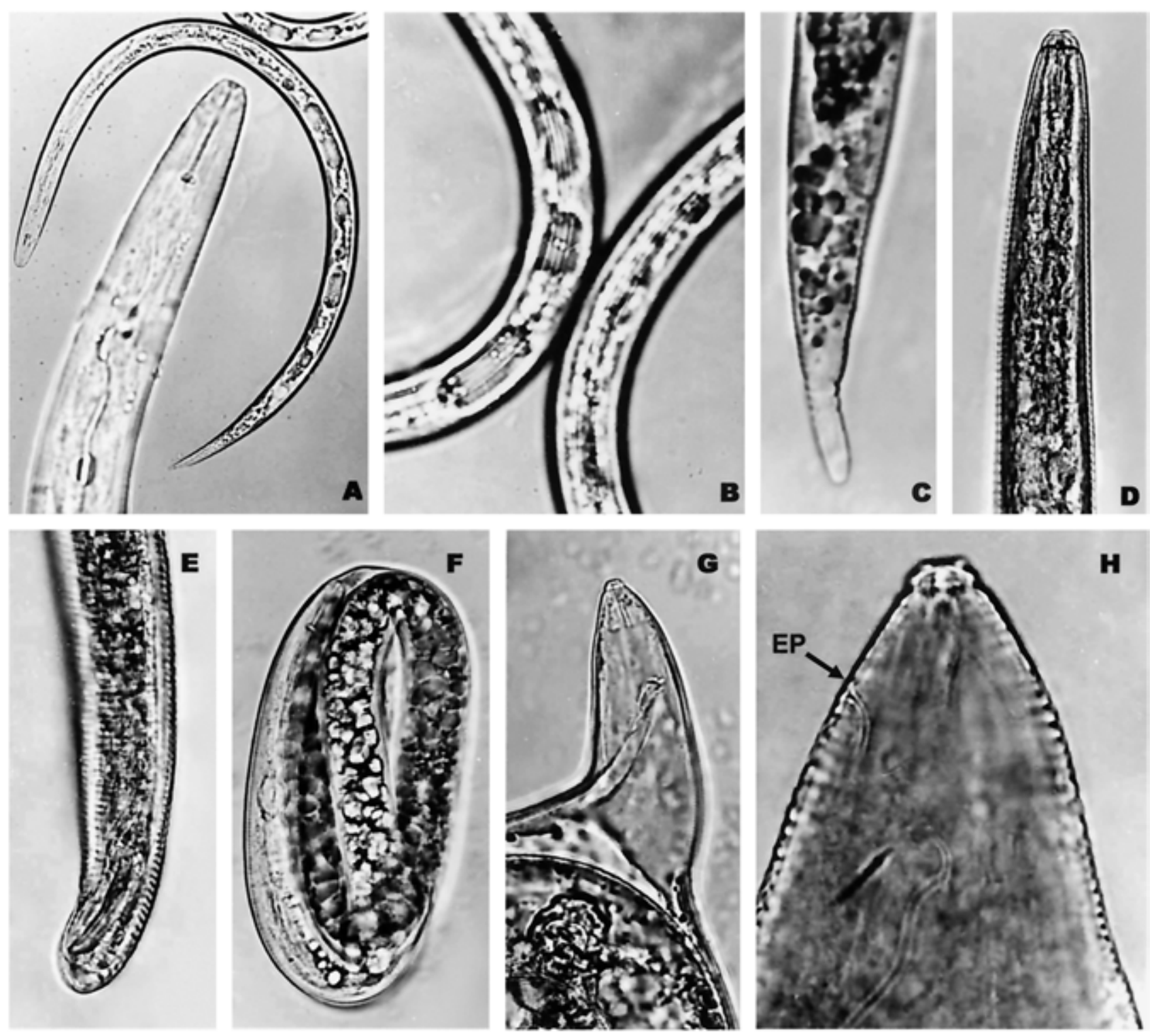

Fig. 3. Photomicrographs of Meloidogyne baetica n. sp. second-stage juveniles: A, whole body and anterior region; B, lateral fields; and $\mathbf{C}$, tail. Male: D, lip region; E, tail; and F, embryonated egg. Female: $\mathbf{G}$, anterior region; and $\mathbf{H}$, lip region (EP, excretory pore). 
the lateral field, about one-third of tail length from anus. Tail elongate-conoid, tapering to a slender, terminal, digitiform process (Fig. 3), $50 \pm 2.3$ (47 to 54) long. Hyaline region of tail $12 \pm 1.2$ (10 to 13) long.

Type host and locality. Roots of wild olive (O. europaea sp. sylvestris) collected from Vejer de la Frontera (Cádiz), southern Spain.

Etymology. The species epithet refers to the Roman Province Baetica that included most of southern Spain. Because of its ability to infect wild and cultivated olives, we suggest the common name, Mediterranean olive root-knot nematode to differentiate it from the olive root-knot nematode M. lusitanica Abrantes and Santos (1).

Type material. Holotype female and paratypes were deposited at the Nematode Collection of the Plant Protection Institute (IPP), Nematology Section of Bari, Italy. Additional juvenile and male paratypes are distributed to the U.S. Department of Agriculture Nematode Collection, Beltsville, MD; University of California Riverside Nematode Collection; University of California Davis Collection; Plant Protection Research Institute, Pretoria, South Africa; and Nematode Collection of the Landbouwhogenschool, Wageningen, the Netherlands.

Diagnosis and relationships. M. baetica n. sp. can be distinguished from other Meloidogyne spp. by the following characteristics: (i) female perineal pattern with distinct inner striae forming marked longitudinal bands throughout the perineum, resembling only that of $M$. artiellia; (ii) excretory pore position anterior to the level of stylet knobs, with EP/ST ratio extremely small (0.5 to 0.8 ); and (iii) $\mathrm{J} 2$ with elongate-conoid tail.
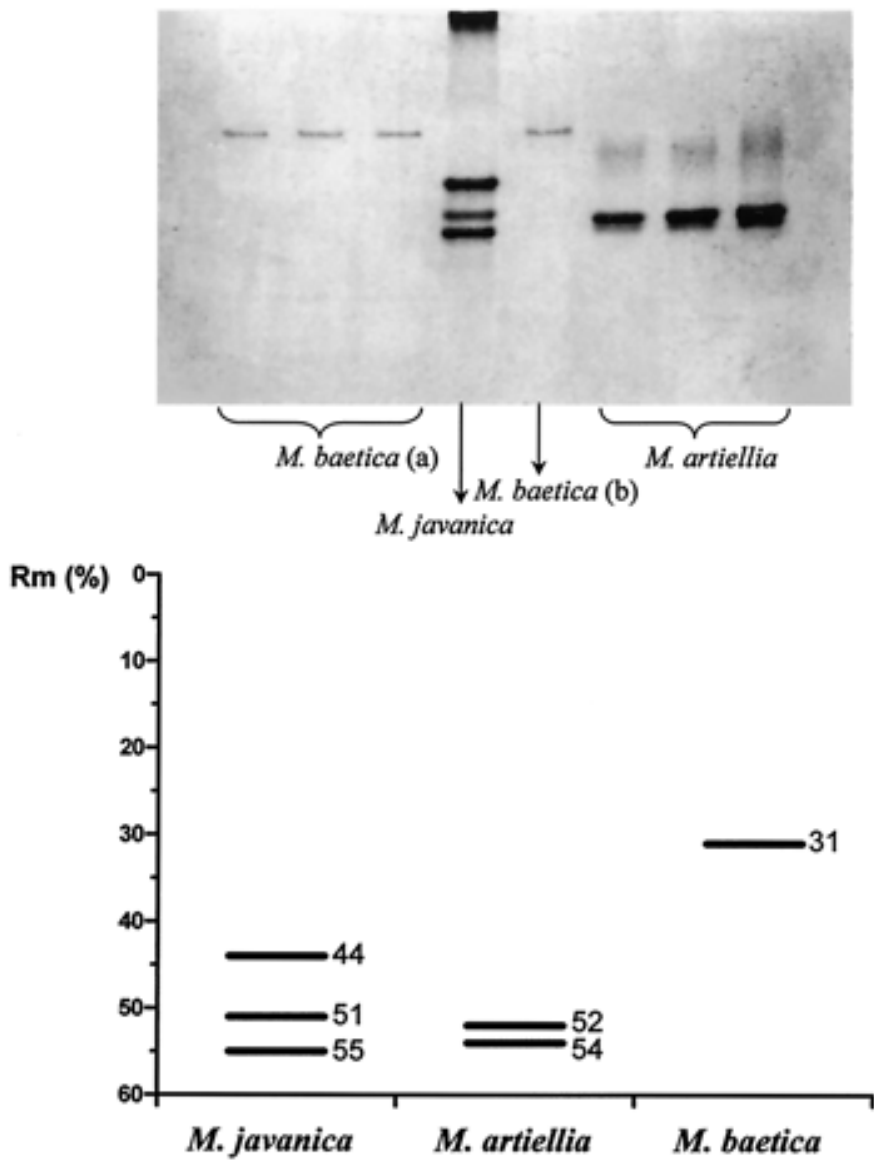

Fig. 4. Esterase electrophoresis pattern of protein homogenates from five (a) and single (b) young egg-laying females of Meloidogyne baetica $\mathrm{n}$. sp., and five young egg-laying females of $M$. artiellia. $M$. javanica is the reference population. Lines correspond to strongly stained bands. Top, esterase patterns; and bottom, relative mobility ( $\mathrm{Rm})$ of esterase bands.
The female perineal pattern morphology of $M$. baetica places it in the Jepson's Group 1 (21), which includes the closely related species $M$. artiellia. The following characters and morphometrics separate $M$. baetica from $M$. artiellia (14): the female excretory pore is located anterior to the level of stylet knobs versus posterior, with an EP/ST ratio of 0.7 versus 1.8, respectively; tail shape and length of $\mathrm{J} 2$, elongate-conoid with 51 (50 to 54) versus distinctly short and blunt with 22 (18 to 26); length of J2 403 (394 to 422 ) versus 364 (334 to 370 ); length of $\mathrm{J} 2$ hyaline tail region 12 (10 to 13 ) versus 4.9 (1.8 to 7.2$)$; and male length 1,811 (1,545 to 2,205 ) versus 1,070 (820 to 1,370). In addition, M. baetica $\mathrm{n}$. sp. differs from $M$. artiellia in the host range and the esterase phenotype and sequences of the ITS1-5.8S-ITS2 region and the D2-D3 fragment of the 28S gene of rDNA.

$M$. baetica clearly differs from the olive root-knot nematode $M$. lusitanica Abrantes and Santos, in the shape of the perineal pattern having fine dorsal outer striae versus medium to high trapezoidal dorsal arch and distinct punctuations in the tail terminus region; position of excretory pore, located anterior to the level of stylet knobs versus posterior, with an EP/ST ratio of 0.7 versus 2.6; and the esterase phenotype, a single esterase band at relative mobility (Rm) 0.31 versus Rm 0.52 (28). Furthermore, M. baetica clearly differs from other root-knot nematodes infecting olive (e.g., $M$. arenaria, $M$. incognita, and $M$. javanica) in the shape of the perineal pattern, esterase phenotypes (28), and molecular characterization of the ITS and D2-D3 fragment of the 28S gene of rDNA.

Esterase isozyme analysis. The isozyme electrophoretic analysis of single- and five-specimen groups of young egg-laying females of $M$. baetica (Fig. 4) revealed a single esterase band at $\mathrm{Rm} 0.31$ that did not occur in the esterase phenotypes of $M$. artiellia or M. javanica (Fig. 4). However, the esterase phenotype of $M$. artiellia revealed two bands at Rm 0.52 and 0.54 (Fig. 4). Similarly, esterase phenotypes from other root-knot nematodes infecting olive (M. arenaria, M. hapla, M. incognita, M. javanica, and $M$. lusitanica) were different from that of $M$. baetica (28). Therefore, these data indicate that $M$. baetica may be clearly separate from these species by the esterase phenotype.

Molecular characterization of $M$. baetica and its relationships to other root-knot nematodes. Amplification of the ITS5.8S-ITS2 of rDNA yielded a single fragment of approximately 800 bp for $M$. baetica. The ITS sequence of $M$. baetica was clearly different from that of all other Meloidogyne spp. assayed. Alignment of ITS regions from Meloidogyne spp. contained many ambiguous positions in the ITS2 sequence, which was omitted from the study. The resulting alignment used for the analysis was $452 \mathrm{bp}$ from the ITS1 and 5.8S gene only. The single phylogenetic tree obtained from maximum parsimony analysis showed that $M$. baetica formed a clade with two populations of $M$. artiellia with high bootstrap support (Fig. 5A). The alignment of the D2-D3 region of $28 \mathrm{~S}$ gene sequences was $700 \mathrm{bp}$ in length. Strict consensus of the five most parsimonious trees is provided in Figure 5B. $M$. baetica formed a moderately supported clade with two $M$. artiellia populations, which occupied a basal position within trees. Thus, substantial sequence divergence (14.2 to $27.2 \%$ and 14.1 to $27.4 \%$ ) and presence of several autopomorphies (31 and 22 nucleotides) in the ITS1-5.8S region and D2-D3 fragment for the new species distinguish $M$. baetica from other studied root-knot nematodes and support its separate specific status.

Histopathology. Both wild olive and cultivated 'Arbequina' and 'Picual' olive planting stocks showed similar disease reaction. Galls induced by $M$. baetica on olive roots were variable in size but relatively small (almost two times the root diameter), and were located commonly along the root axis but rarely on the root tip (Fig. 6). Numerous lateral roots arising from galled regions were also galled. More than $45 \%$ of arbitrarily selected individual galls (collected in spring samplings) contained an egg mass (Fig. 6). Usually galls contained more than one nematode female. Occasionally an egg mass was found inside the cortical root tissue 
(Fig. 7), but the majority of egg masses were observed at the root surface (Fig. 6).

Comparative histological observation of healthy and $M$. baeticainfected wild olive roots showed cellular alterations in the cortex, endodermis, pericycle, and vascular parenchyma induced by the nematode. In the permanent feeding sites, the nematode induced formation of large multinucleate giant cells adjacent to the vascular tissues both in wild and cultivated ('Arbequina' and 'Picual')

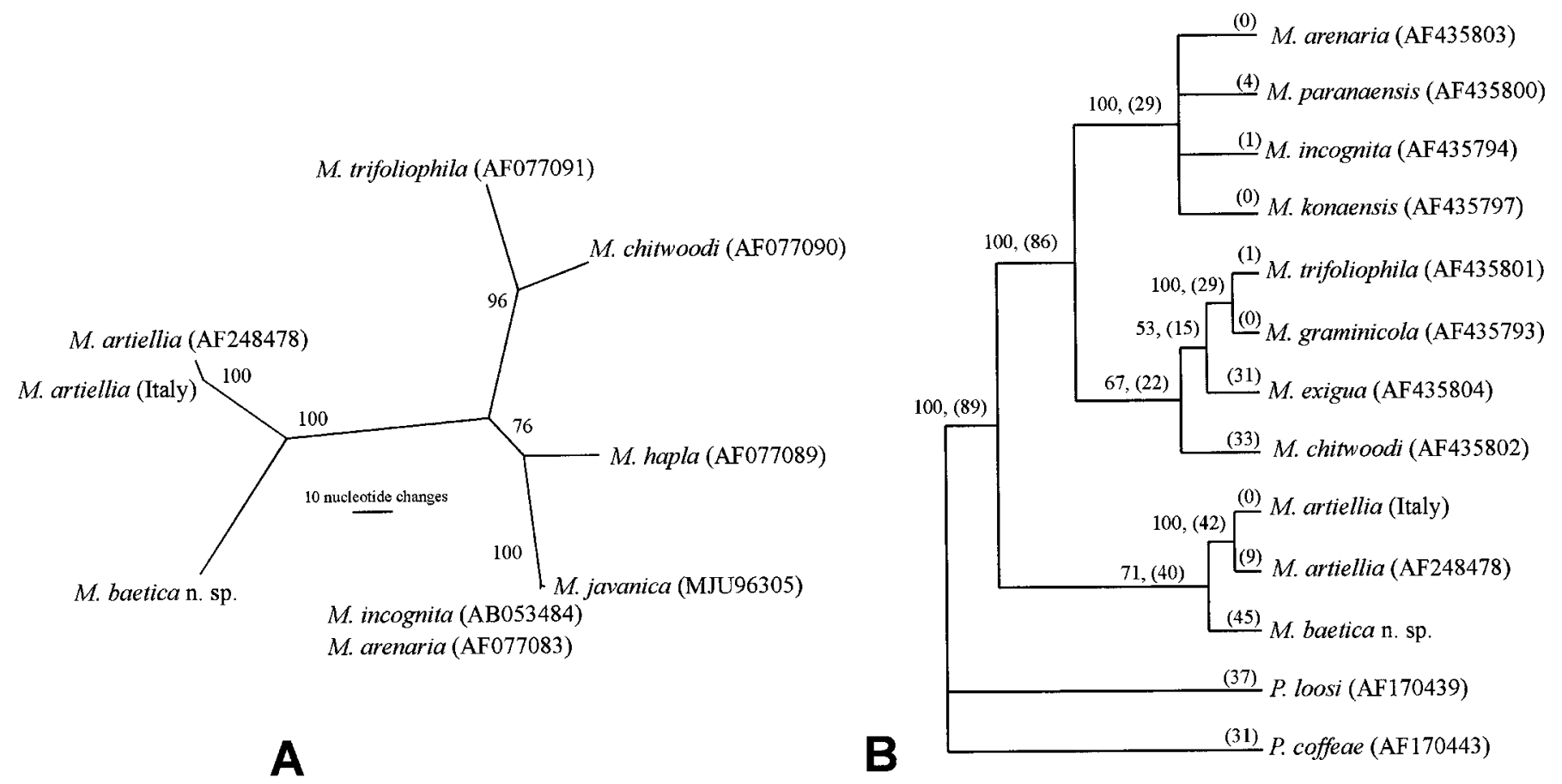

Fig. 5. Phylogenetic relationships of Meloidogyne baetica n. sp. with other root-knot nematodes. A, Unrooted maximum parsimonious tree obtained from the analysis of the alignment for nine sequences of the internal transcribed spacer 1 (ITS1) and 5.8S gene (tree length $=253$; number of parsimony informative characters $=114$; consistency index $(\mathrm{CI})=0.8854$; homoplasy index $(\mathrm{HI})=0.1146$; and retention index $(\mathrm{RI})=0.8722)$. B, Strict consensus of five most parsimonious trees obtained from the analysis of the alignment of the D2-D3 fragment of $28 \mathrm{~S}$ gene sequences for 10 root-knot nematode species and two Pratylenchus spp. used as outgroups (tree length $=543$; number of parsimony informative characters $=247 ; \mathrm{CI}=0.8214 ; \mathrm{HI}=0.1786$; and RI $=0.8594$ ). Bootstrap values and nucleotide changes (in parenthesis) are given in the appropriate clade.
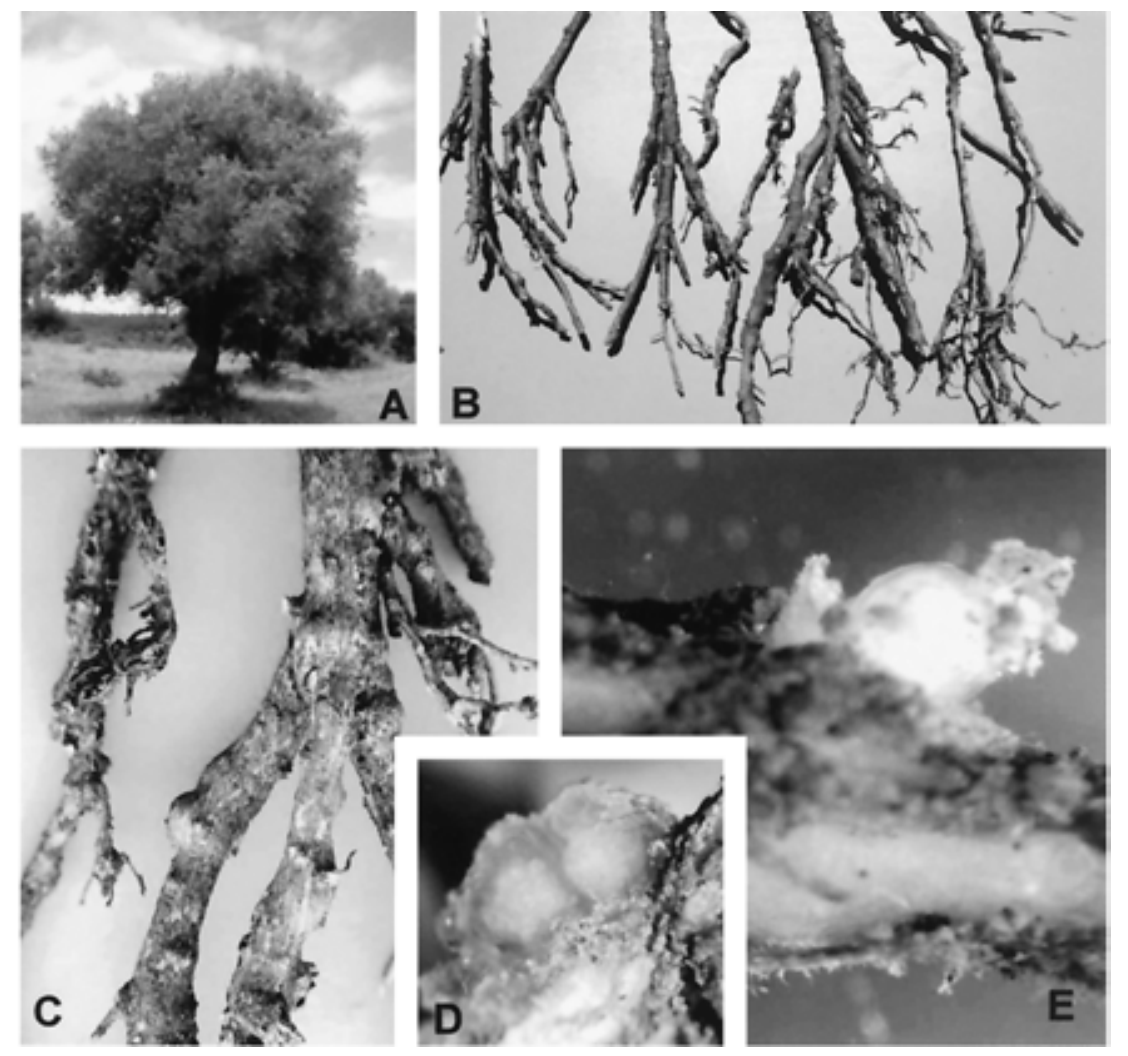

Fig. 6. Wild olive infected by Meloidogyne baetica $\mathrm{n}$. sp. in an A, adult tree. B and C, Feeder roots showing severe root galling. D and E, Root galls showing mature egg masses. 

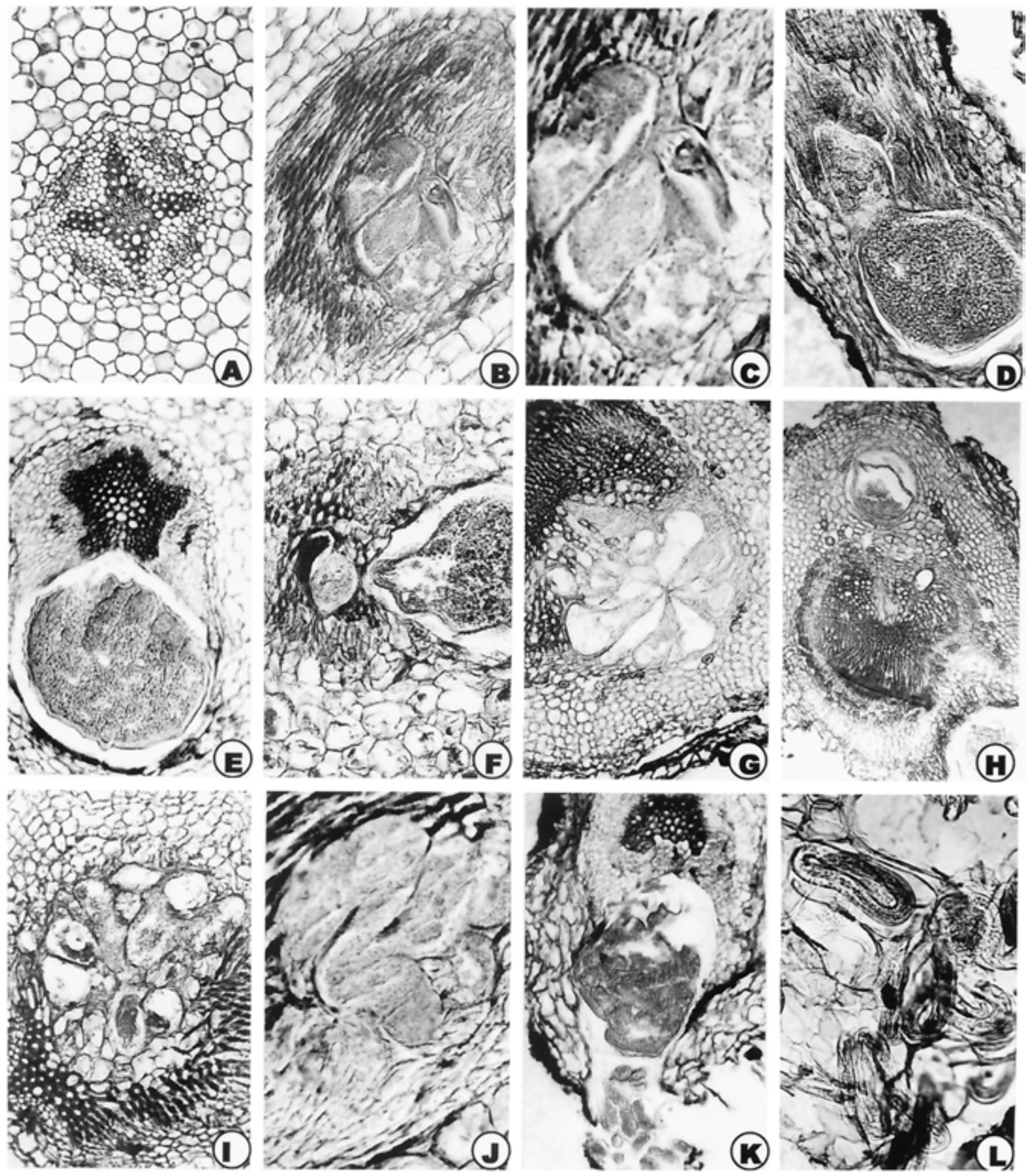

Fig. 7. Histopathology of Meloidogyne baetica n. sp. on wild and cultivated olives. A, Transverse section of a young healthy olive root (cv. Arbequina). B, C, and F, Transverse sections of wild olive roots showing giant cells. D and E, Longitudinal and transverse sections of wild olive roots showing adult females. G and $\mathbf{H}$, Transverse sections of roots of olive planting stock (cv. Picual) infected by M. baetica. I to K, Transverse sections of roots of olive planting stock (cv. Arbequina) infected by M. baetica. L, Transverse section of root of olive planting stock (cv. Arbequina) showing egg masses with embryonated eggs.

olives. This formation led to disorganization and disruption of xylem elements and primary phloem cells (Fig. 7). Nematode feeding sites comprised three to eight giant cells that surrounded the lip region of a single female (Fig. 7B and C). Undersized feeding cells were associated with preadult males. Active multinucleated giant cells contained granular cytoplasm, thickened cell wall, and numerous hypertrophied nuclei and nucleoli. Dense giant cell cytoplasm lined deeply stained thick walls. The histological modifications induced by $M$. baetica in roots of wild and cultivated olive cvs. Arbequina and Picual revealed a typical susceptible reaction to infection by the nematode. The development and parasitic habit of $M$. baetica that we observed in wild olive and cvs. Arbequina and Picual were similar to those reported for Meloidogyne spp. on olive $(2,27)$.

Host plant bioassay. $M$. baetica induced small galls on roots of tomato (cv. Roma), but no reproduction of the nematode occurred in them. Feeding sites induced by $M$. baetica on tomato usually consisted of a group of three to seven irregularly undersized giant cells. These giant cells were surrounded by limited hyperplastic and hypertrophied tissue (Fig. 8). Restricted nematode 

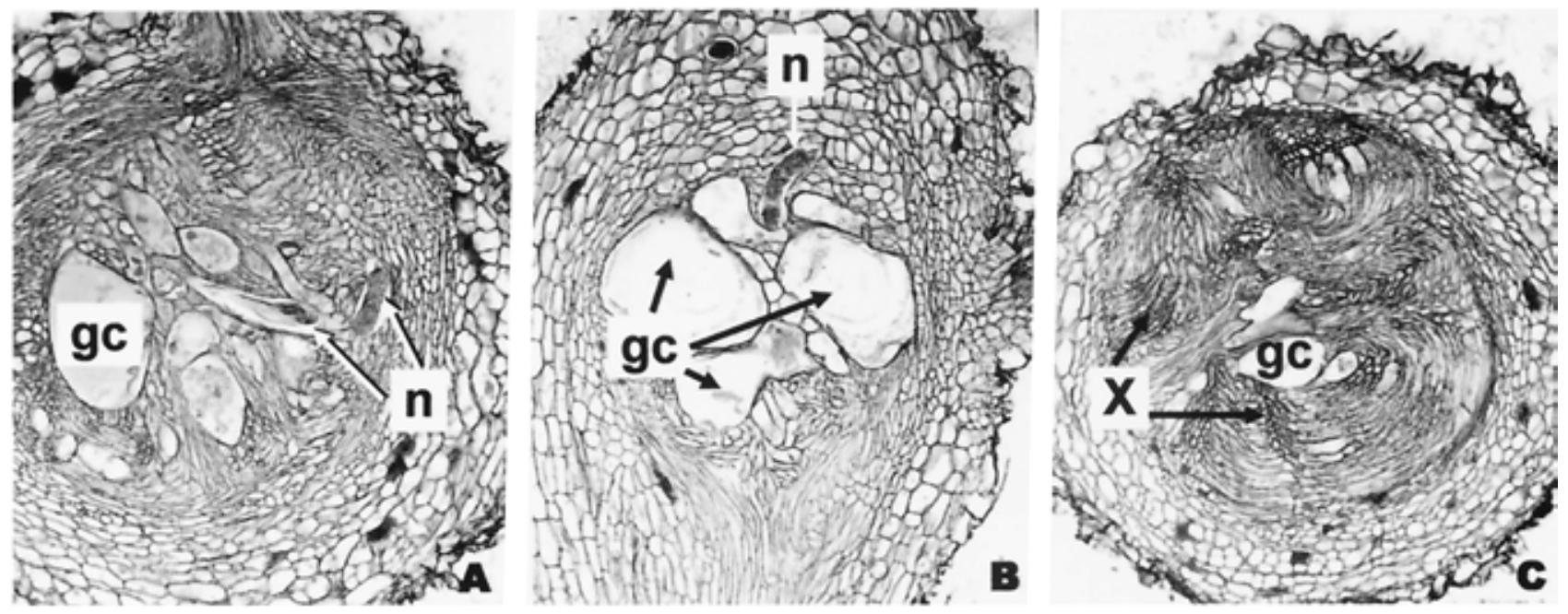

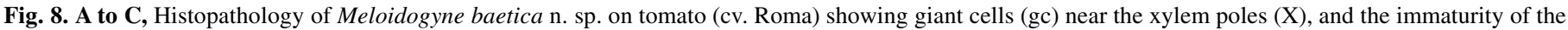
nematode $(n)$.

development was associated with this kind of feeding site. Giant cells had slightly thickened walls, and the cytoplasm, which contained many small vacuoles, was moderately dense (Fig. 8). Histological modifications induced by $M$. baetica in roots of tomato revealed a typical resistant reaction to infection by the nematode.

No infections and no galled roots were found on chickpea and pea, representing a clear biological difference with $M$. artiellia, because both plants are very good hosts of the latter (11). Similarly, no infections and no galled roots were found on wild olive or cultivated 'Arbequina' and 'Picual' olive planting stocks artificially inoculated with $M$. artiellia, also representing a clear biological difference between $M$. artiellia and M. baetica.

\section{ACKNOWLEDGMENTS}

Research was supported in part by a bilateral Research Program funded by Consejo Superior de Investigaciones Científicas (CSIC), Spain, and Consiglio Nazionale delle Ricerche (CNR), Italy. We thank R. M. Jiménez-Díaz (IAS-CSIC) and F. Lamberti (IPP-Bari-CNR) for reviewing the manuscript prior to submission; I. M. de O. Abrantes, (Portugal) for help with the isozyme electrophoretic studies; and J. A. Navas-Cortés (IAS-CSIC) and T. Paulitz, USDA-ARS, Pullman, WA, for suggestions.

\section{LITERATURE CITED}

1. Abrantes, I. M. de O., and Santos, M. S. N. 1991. Meloidogyne lusitanica n. sp. (Nematoda: Meloidogynidae), a root-knot nematode parasitizing olive tree (Olea europaea L.). J. Nematol. 23:210-224.

2. Abrantes, I. M. de O., Vovlas, N., and Santos, M. S. N. 1992. Host-parasite relationships of Meloidogyne javanica and M. lusitanica with Olea europaea. Nematologica 38:320-328.

3. Barranco, D. 1999. Variedades y patrones. Pages 63-89 in: El Cultivo del Olivo. D. Barranco, R. Fernández-Escobar, and L. Rallo, eds. Ediciones Mundi-Prensa, Madrid.

4. Blok, V. C., Phillips, M. S., and Fragette, M. 1997. Comparison of sequences from the ribosomal DNA intergenic region of Meloidogyne mayaguensis and other major tropical root-knot nematodes. J. Nematol. 29:16-22.

5. Castillo, P., Vovlas, N., Nico, A. I., and Jiménez-Díaz, R. M. 1999. Infection of olive trees by Heterodera mediterranea in orchards in southern Spain. Plant Dis. 83:710-713.

6. Coolen, W. A. 1979. Methods for extraction of Meloidogyne spp. and other nematodes from roots and soil. Pages 317-329 in: Root-knot Nematodes (Meloidogyne Species). Systematics, Biology, and Control. F. Lamberti and C. E. Taylor, eds. Academic Press, London.

7. De Giorgi, C., Veronico, P., De Luca, F., Natilla, A., Lanave, C., and Pesole, G. 2002. Structural and evolutionary analysis of the ribosomal genes of the parasitic nematode Meloidogyne artiellia suggests its ancient origin. Mol. Biochem. Parasitol. 124:91-94.
8. De Ley, I. T., Karssen, G., De Ley, P., Vierstraete, A., Waeyenberge, L., Moens, M., and Vanfleteren, J. 1999. Phylogenetic analyses of internal transcribed spacer region sequences within Meloidogyne. (Abstr.) J. Nematol. 31:530-531.

9. De Ley, P., Félix, M. A., Frisse, L. M., Nadler, S. A., Sternberg, P. W., and Thomas, W. K. 1999. Molecular and morphological characterisation of two reproductive species with mirror-image anatomy (Nematoda: Cephalobidae). Nematology 1:591-612.

10. Diab, K. A., and El-Eraki, S. 1968. Plant-parasitic nematodes associated with olive decline in the United Arab Republic. Plant Dis. Rep. 52: 150-154.

11. Di Vito, M., Greco, N., and Zaccheo, G. 1985. On the host range of Meloidogyne artiellia. Nematol. Mediterr. 13:207-212.

12. Duncan, L. W., Inserra, R. N., Thomas, W. K., Dunn, D., Mustika, I., Frisse, L. M., Mendes, M. L., Morris, K., and Kaplan, D. 1999. Molecular and morphological analysis of isolates of Pratylenchus coffeae and closely related species. Nematropica 29:61-80.

13. Esbenshade, P. R., and Triantaphyllou, A. C. 1985. Use of enzyme phenotypes for identification of Meloidogyne (Nematoda: Tylenchida). J. Nematol. 17:6-20.

14. Esser, R. P. 1986. A water agar en face technique. Proc. Helminthol. Soc. Wash. 53:254-255.

15. Food and Agriculture Organization of The United Nations (FAO). 2002. Faostat Agriculture Data. Published online by FAO, Italy.

16. Franklin, M. T. 1961. A British root-knot nematode, Meloidogyne artiellia $\mathrm{n}$. sp. J. Helminthol. R.T. Leiper Suppl. 85-92.

17. Hartman, K. M., and Sasser, J. N. 1985. Identification of Meloidogyne species on the basis of differential host assay and perineal-pattern morphology. Pages 67-77 in: An Advanced Treatise on Meloidogyne. Vol. 2, Methodology. K. R. Barker, C. C. Carter, and J. J. Sasser, eds. North Carolina State University Graphics, Raleigh.

18. Hugall, A., Stanton, J., and Moritz, C. 1999. Reticular evolution and the origins of ribosomal internal transcribed spacer in apomictic Meloidogyne. Mol. Biol. Evol. 16:157-164

19. Hussey, R. S., and Barker, K. R. 1973. A comparison of methods of collecting inocula of Meloidogyne spp. including a new technique. Plant Dis. Rep. 57:1025-1028.

20. Ibrahim, S. K., and Perry, R. N. 1993. Use of esterase patterns of females and galled roots for the identification of species of Meloidogyne. Fundam. Appl. Nematol. 16:187-191.

21. Jepson, S. B. 1987. Identification of Root-Knot Nematodes (Meloidogyne Species). CAB International, Wallingford, UK.

22. Johansen, D. A. 1940. Plant Microtechnique. McGraw-Hill Book Co., New York.

23. Karssen, G., Van Hoenselaar, T., Verkerk-Bakker, B., and Janssen, R. 1995. Species identification of root-knot nematodes from potato by electrophoresis of individual females. Electrophoresis 16:105-109.

24. Lamberti, F., and Baines, R. C. 1969. Pathogenicity of four species of Meloidogyne on three varieties of olive trees. J. Nematol. 1:111-115.

25. Lamberti, F., and Baines, R. C. 1969. Effect of Pratylenchus vulnus on the growth of 'Ascolano' and 'Manzanillo' olive trees in a glasshouse. Plant Dis. Rep. 53:557-558.

26. Lamberti, F., and Vovlas, N. 1993. Plant parasitic nematodes associated with olive. EPPO Bull. 23:481-488 
27. Nico, A. I., Rapoport, H. F., Jiménez-Díaz, R. M., and Castillo, P. 2002. Incidence and population density of plant-parasitic nematodes associated with olive planting stocks at nurseries in southern Spain. Plant Dis. 86:1075-1079.

28. Pais, C. S., and Abrantes, I. M. de O. 1989. Esterase and malate deshydrogenase phenotypes in Portuguese populations of Meloidogyne species. J. Nematol. 21:342-346.

29. Powers, T. O., Todd, T. G., Burnell, A. M., Murray, P. C. B., Fleming, C. C., Szalanski, A. L., Adams, B. A., and Harris, T. S. 1997. The rDNA internal transcribed spacer as a taxonomic marker for nematodes. J. Nematol. 29:441-450.

30. Rivas Martínez, S. 1982. Etages bioclimatiques, secteurs chorologiques et series de végetation de l'Espagne méditerranéenne. Ecol. Mediterr. 8:175-288.

31. Sasanelli, N., Fontanazza, G., Lamberti, F., D’ Addabbo, T., Patumi, M., and Vergari, G. 1997. Reaction of olive cultivars to Meloidogyne species. Nematol. Mediterr. 25:183-190.

32. Sasser, J. N., and Carter, C. C. 1985. An Advanced Treatise on Meloidogyne. Vol. I, Biology and Control. North Carolina State University Graphics, Raleigh.
33. Schmitz, B., Burgermeister, W., and Braasch, H. 1998. Molecular genetic classification of Central European Meloidogyne chitwoodi and M. fallax populations. Nachrichtenbl. Deutschen Pflanzenschutzd. 50:310-317.

34. Seinhorst, J. W. 1966. Killing nematodes for taxonomic study with hot f.a. 4:1. Nematologica 12:178.

35. Subbotin, S., Waeyenberge, A. L., and Moens, M. 2000. Identification of cyst forming nematodes of the genus Heterodera (Nematoda: Heteroderidae) based on the ribosomal DNA-RFLPs. Nematology 2: 153-164.

36. Swofford, D. L. 1998. PAUP. Phylogenetic Analysis Using Parsimony. Version 4. Sinauer Associates, Sunderland, MA.

37. Wishart, J., Phillips, M. S., and Blok, V. C. 2002. Ribosomal intergenic spacer: A polymerase chain reaction diagnostic for Meloidogyne chitwoodi, M. fallax, and M. hapla. Phytopathology 92:884-892.

38. Zijlstra, C., Uenk, B. J., and Van Silfhout, C. H. 1997. A reliable, precise method to differentiate species of root-knot nematodes in mixtures on the basis of ITS-RFLPs. Fundam. Appl. Nematol. 20:59-63.

39. Zohary, D., and Spiegel-Roy, P. 1975. Beginning of fruit growing in the old world. Science 187:319-327. 